\title{
THE BAT FAUNA (CHIROPTERA) OF THE UZHANSKYI NATIONAL PARK
}

\author{
Nelia Koval $^{1}$, Andriy-Taras Bashta ${ }^{2}$ \\ ${ }^{1}$ Uzhanskyi National Nature Park (Velykyi Bereznyi, Ukraine) \\ ${ }^{2}$ Institute of Ecology of the Carpathians, NAS of Ukraine (Lviv, Ukraine) \\ Correspondence to: N. Koval; Uzhanskyi National Nature Park; Nezalezhnosti St. 7, Velykyi Bereznyi, Zakarpatska \\ Oblast, 89000 Ukraine; e-mail: nelya.kowal@gmail.com
}

\begin{abstract}
The bat fauna (Chiroptera) of the Uzhanskyi National Park. - N. Koval, A.-T. Bashta. - The results of research on bats conducted in the territory of the Uzhanskyi National Park during 2008-2016 are presented. The bat fauna of the Park is represented by 20 species. A large area of old deciduous and mixed forests with high number of hollow trees explains the predominance of forest-dwelling species. The presence of a plenty of underground cavities creates favorable conditions for the settlement of troglophyle bat species. The Park's area plays an important role in the existence of bat populations in periods of reproduction and hibernation. The present study also involved examination of 19 sacral buildings; about $60 \%$ of them are important shelters for bats. Since 2015, ultrasound bat investigations (using Batcorder 3.0 stationary detector) have been conducted. These studies clarify the species composition and biotope preferences of bats in the Park. Analysis of bat ultrasonic signals confirmed the occurrence of Myotis bechsteinii here.
\end{abstract}

Key words: Chiroptera, species composition, biotope preference, Uzhanskyi National Park.

Фауна рукокрилих (Chiroptera) Ужанського національного парку. - Н. Коваль, А.-Т. Башта. Представлено результати досліджень рукокрилих на території Ужанського НПП протягом 2008-2016 pp. Загалом на сьогодні фауна кажанів парку нараховує 20 видів. Значна площа старих листяних і мішаних лісів 3 великою кількістю дуплавих дерев зумовила переважання лісових видів рукокрилих. Наявність значної кількості підземних порожнин створює сприятливі умови для поселення осілих, печерних видів. Територія парку відіграє важливу роль для існування популяцій кажанів у виводковий і зимовий періоди. Обстежено 19 сакральних споруд і виявлено, що понад 60 \% 3 них є важливим об'єктами для поселення рукокрилих. 32015 р. на території парку проводяться дослідження 3 використанням стаціонарного ультразвукового детектора «Batcorder 3.0». Ці дослідження дозволять уточнити видовий склад i біотопний розподіл рукокрилих на території парку. Аналіз записів ультразвукових сигналів кажанів за польовий сезон 2015 р. підтвердив трапляння на території Парку виду Myotis bechsteinii.

Ключові слова: кажани, хіроптерофауна, видовий склад, біотопний розподіл, Ужанський НПП.

\section{Introduction}

The Uzhanskyi National Park is located between altitudes of $220-1250 \mathrm{~m}$ a.s.l on the southern macroslope of the Eastern Beskids, where the Park's flora reflects the geobotanical features of the massif. There are four elevation zones within the park: 1) beech forests, 2) fir-beech and beech-fir forests, 3) disjunctive krummholz zone of Alnus viridus, and 4) subalpine meadows. The total territory of the Park is 39,159 ha, $65 \%$ of which is covered by forests.

Most of the forested area is situated in the frontier along the state border with Slovakia and Poland. These are anthropogenically little disturbed mature forests with hollow trees serving as shelters for summering bats. Such a large forest cover in the territory contributed to the predominance of forest-dwelling species in the bat fauna of the Park. Several forest management measures destroy the natural habitats of these bat species leading to a decrease in population abundance thus issues of protection of bats and their habitats became extremely important. 
The territory of the Uzhanskyi Park is rich in different underground shelters of both natural and artificial origin. Natural shelters are represented by pseudokarstic caves located mainly on the top of the ridges. These caves are formed by flysch carbonate rocks and have narrow corridors that alternate with spacious halls. The halls are used by bats mainly as wintering shelters. Artificial shelters are represented by isolated adits that can be easily accessed by both humans and bats owing to their large width.

The presence of underground cavities and the influence of warm air currents from the Pannonian plain contributed to the significant number of Mediterranean troglophyle species. Besides, there are 15 human settlements within the Park that contribute to the dispersal of synanthrope bat species. Sacral buildings, in particular churches, are present in each village and they turned out to be the most suitable for maternity colonies.

The aim of the present work is to clarify the species composition of bats in the Uzhanskyi National Park, to study the distribution of species and their confinement to certain types of biotopes, as well as to estimate the prospects of conservation of bats within the Park.

\section{Material and methods}

Primary inventory research on species composition of bats in the Uzhanskyi Park had been carried out since the 2000s by scientists of the Park's Research Department (M. Kapral and I. Ivaneha). The results were recorded in the "Chronicles of Nature" for 2001-2008 titled "Investigation of the course of natural processes and interrelations in ecosystems of the Park." The first annotated checklist of the bat fauna included 11 species (Krichfalushiy et al., 2001), although the list needed to be clarified and supplemented by results of current research. More detailed field studies have been conducted by the authors of this paper since 2009. Methodological approaches used in this work follow those presented in "The bats workers' manual" (Mitchell-Jones, McLeish, 1999) and "Bats of Ukraine and adjacent countries: a guide for field investigations" (Zagorodniuk et al., 2002).

Research results were partly published in a number of articles (Bashta, Koval, $2013 \mathrm{a}, 2013 \mathrm{~b}$, 2014). All basic methods were used during field investigations: visual examination of locations suitable for use during migration and summering, examination of potential wintering shelters, catching by nets, ultrasonic studies using mobile and stationary detector devices. During ultrasonic research, Pettersson Elektronik AB (D-230 i D-240x) and Tranquility Transect detectors were used.

Recordings of voices of bats were carried out by stereophonic (Sony WM-D6C) and digital (ZOOM H-2) recorders. Analysis of records was done by computer programme "BatSound." It was accepted during analysis that if the interval between subsequent "series" of signals were $1 \mathrm{sec}$ or more than they were considered to be signals of different individuals. On the contrary, if the interval between the "series" was less than $1 \mathrm{sec}$, than they were considered to be signals of a single individual (Miller, 2001).

Research on bats in frames of international project "Acoustic monitoring of bats in the Ukrainian Carpathians" started in 2015 and it was financially supported by the Frankfurt Zoological Society, Germany and the Ukrainian Society for Protection of Birds. The research partner of the project was the Institute of Animal Ecology and Nature Education, Germany.

The Batcorder 3.0 ultrasonic detector was used to record voices of bats. It was set up in different biotopes, including primeval and mature forests with different tree species composition, glades, and also near rivers, streams, and ponds. The use of automatic monitoring systems allows the high density of research localities in separate representative sites.

Collected data were processed and analysed by research scientists of the Institute of Ecology of the Carpathians, Ukraine and the Institute of Animal Ecology and Nature Education, Germany.

\section{Results and discussion}

The bat fauna of the Uzhanskyi National Park was not studied in the past. In the middle 1990s, only one species was known for the territory, the pond bat - Myotis dasycneme (Krochko, 1994). 
Table 1. Bat species recorded in the Uzhanskyi National Park

Таблиця 1. Видовий склад рукокрилих, виявлених на території Ужанського НПП

\begin{tabular}{|c|c|c|c|c|}
\hline $\begin{array}{l}\text { Species } \\
\text { Вид }\end{array}$ & $\begin{array}{c}\text { Summer } \\
\text { Літній період }\end{array}$ & $\begin{array}{c}\text { Autumn } \\
\text { Осінній період }\end{array}$ & $\begin{array}{c}\text { Winter } \\
\text { Зимовий період }\end{array}$ & $\begin{array}{l}\text { Maternity colonies } \\
\text { Виводкові колонії }\end{array}$ \\
\hline Rhinolophus ferrumequinum & $\mathrm{V}$ & - & $\mathrm{V}$ & - \\
\hline Rhinolophus hipposideros & $\mathrm{V}, \mathrm{N}, \mathrm{D}$ & $\mathrm{V}$ & $\mathrm{V}$ & + \\
\hline Myotis myotis & D & $\mathrm{D}$ & $\mathrm{V}$ & - \\
\hline Myotis bechsteinii & $\mathrm{D}$ & $\mathrm{D}$ & - & - \\
\hline Myotis dasycneme & $\mathrm{D}$ & $\mathrm{V}$ & $\mathrm{V}$ & - \\
\hline Myotis nattereri & $\mathrm{V}, \mathrm{D}$ & D & - & - \\
\hline Myotis daubentonii & $\mathrm{V}, \mathrm{D}$ & $\mathrm{V}, \mathrm{N}, \mathrm{D}$ & - & - \\
\hline Myotis mystacinus & $\mathrm{V}, \mathrm{N}, \mathrm{D}$ & - & - & - \\
\hline Myotis emarginatus & - & - & $\mathrm{V}$ & - \\
\hline Myotis brandtii & $\mathrm{D}$ & - & $\mathrm{V}$ & - \\
\hline Plecotus auritus & $\mathrm{V}, \mathrm{D}$ & $\mathrm{D}$ & $\mathrm{V}$ & + \\
\hline Barbastella barbastellus & $\mathrm{V}, \mathrm{D}$ & $\mathrm{D}$ & $\mathrm{V}$ & - \\
\hline Nyctalus noctula & $\mathrm{D}$ & $\mathrm{D}$ & - & - \\
\hline Nyctalus leisleri & $\mathrm{N}$ & - & - & - \\
\hline Pipistrellus pipistrellus & $\mathrm{D}$ & $\mathrm{N}, \mathrm{D}$ & - & + \\
\hline Pipistrellus pygmaeus & $\mathrm{D}$ & $\mathrm{D}$ & - & - \\
\hline Pipistrellus nathusii & $\mathrm{N}, \mathrm{D}$ & - & - & - \\
\hline Vespertilio murinus & $\mathrm{D}$ & $\mathrm{D}$ & - & - \\
\hline Eptesicus serotinus & $\mathrm{D}$ & $\mathrm{D}$ & - & + \\
\hline Eptesicus nilssonii & $\mathrm{D}$ & $\mathrm{D}$ & - & - \\
\hline
\end{tabular}

Symbols used: V — visual observations, $\mathrm{D}$ - records by detectors, $\mathrm{N}$ - catches by nets.

Later on, four other species (Rhinolophus hipposideros, Myotis myotis, M. dasycneme, and Plecotus auritus) were recorded during exploration of caves by speleologists from the club "Lynx" based in Uzhhorod (person. comm. by M. Levinets, 2002-2012). Since 2009, we have conducted our own investigation that covered the entire territory of the Park, as well as some other sites located in adjoining territories. It was clarified that the bat fauna of the Park includes 20 species, among which 19 are confirmed by recent records (Table 1 ).

During earlier stages of our studies, we did not record two species, Myotis dasycneme and $M$. emarginatus, which were found by other researchers. A specimen of M. emarginatus was recorded earlier in a cave on Krasiia Mt. (data of M. Levinets, 2009), while wintering individuals of M. dasycneme were reported from Adit N 1 near Zahorb village in 2001-2006 (data of I. Ivaneha and M. Kapral). The presence of this species in 6 of 10 explored sites we could confirm only in 2015 by Batcorder. During field studies, we also recorded in most of the sites another species, $M$. bechsteinii, that evidence about its wide distribution in the Uzhanskyi Park.

During research in the summer and winter seasons, 5 species were recorded such as Rhinolophus ferrumequinum, R. hipposideros, Myotis dasycneme, Barbastella barbastellus, Plecotus auritus. The wintering of some other species, in particular Myotis daubentonii, M. mystacinus, Eptesicus serotinus, and E. nilssonii in the territory is also possible. Investigations during the "warm" period (summer-autumn) by using different methods revealed 17 (88.9\%) species. Maternity colonies of only four species were discovered: Rhinolophus hipposideros, Plecotus auritus, Eptesicus serotinus, and Pipistrellus pipistrellus. On the other hand, six species were recorded during hibernation: Rhinolophus hipposideros, R. ferrumequinum, Myotis myotis, M. brandtii, Plecotus auritus and Barbastella barbastellus. Churches in the Park's territory are important sites for bats providing suitable conditions owing to their microclimate and minor human disturbance. Among 20 churches situated in the region of the Uzhanskyi National Park 19 were examined, and in 12 churches $(63.2 \%)$ bats or signs of their presence (guano, feeding stools) were revealed. Bats settled not only in old wood churches but also in attics covered by metal sheets. 


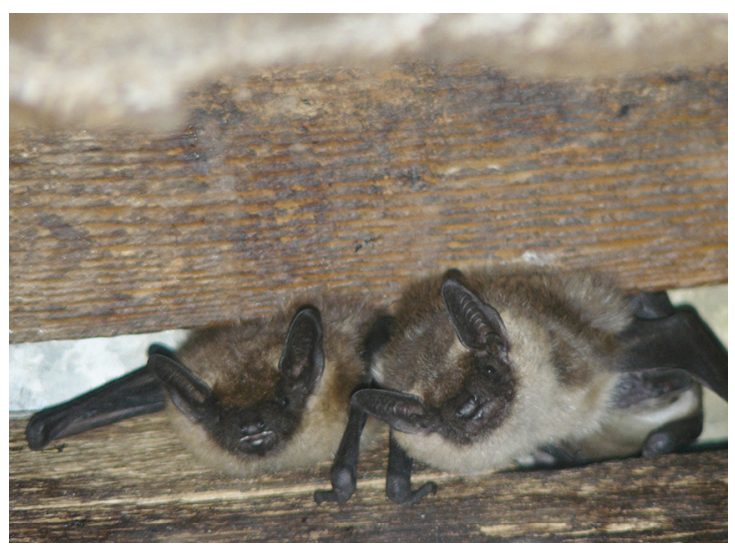

Fig. 1. A part of Eptesicus serotinus colony in a church attic, Volosianka village.

Рис. 1. Фрагмент колонії Eptesicus serotinus на дахові церкви у с. Волосянка.

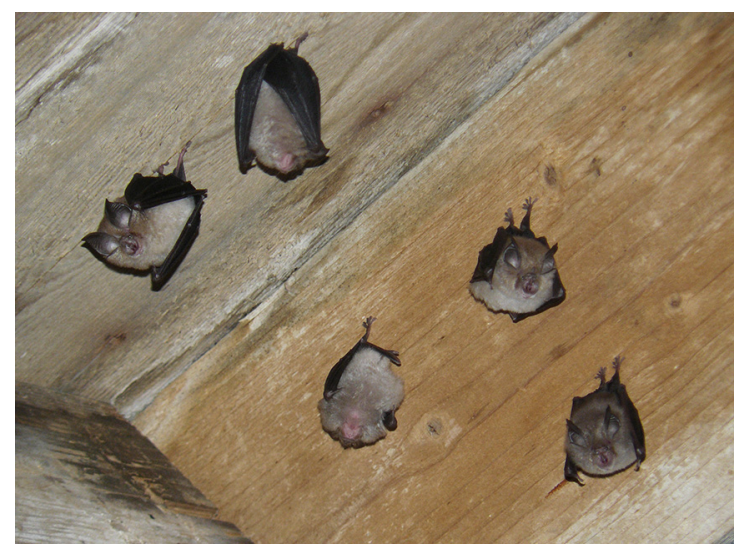

Fig. 2. A colony of Rhinolophus hipposideros in a church attic, Tykhyi village.

Рис. 2. Колонія Rhinolophus hipposideros на даху церкви у с. Тихий.

Five species of bats were recorded in the explored churches: Rhinolophus hipposideros (Fig. 2), Plecotus auritus, Barbastella barbastellus, Pipistrellus pipistrellus, and Eptesicus serotinus (Fig. 1). The most abundant species was Eptesicus serotinus, which was recorded in 6 churches $(31.6 \%$ of all churches, $50 \%$ of churches inhabited by bats). Maternity colonies of Rhinolophus hipposideros (in 5 churches, $26.3 \%$ and $42.7 \%$, respectively, including 3 maternity colonies consisting of 57, 43, and 20 individuals), Plecotus auritus (23 individuals), Pipistrellus pipistrellus and Eptesicus serotinus (ca. 20 individuals) were found as well.

In 2012-2014, during censuses by detectors in the summer-autumn, 8 species of bats (not taking into consideration Myotis and Plecotus) were recorded. The most abundant species was Eptesicus serotinus, the record frequency of which in different habitats made up 12 to $52 \%$ of signals. Deep in the mountain ridges, a significant part of records (to $30 \%$ ) was Eptesicus nilssonii. The only record of a female of Nyctalus leisleri was caught by nets in vicinities of Zhornava village in June, 2017. In 2015, signals of 15 bat species were recorded by batcorder. Considering that acoustic species identification is limited by the similarity of signals for the genera Plecotus, Myotis, and Pipistrellus, findings of some other bat species during further studies should be expected.

We also carefully examined 11 underground cavities in different seasons, where 7 species of bats were found: three of them (Rhinolophus hipposideros, Myotis nattereri, and M. mystacinus) in the summer-autumn, and five (Rhinolophus ferrumequinum, R. hipposideros, Myotis myotis, $M$. brandtii, and Plecotus auritus) in the winter.

The Lubnia cave complex turned out to be quite interesting. It consists of 5 caves located close to each other in a mature beech forest and plays an important role in the life of bats during the whole year. In total, at least 7 species of bats were recorded in these caves in different seasons. In particular, wintering colonies of Rhinolophus hipposideros (in one cave 59, in another one 11 individuals: data of M. Levinets and V. Pokynchereda, 2012) and Myotis myotis (18 individuals: data of N. Koval, 2011) were revealed.

Adits near Zahorb village are also important sites for bats in different seasons. These adits are located on a low rocky slope, next to each other. At the foot of the ridge runs the Uzh river and its tributary, the Svitla river. Bat censuses in these adits have been carried out regularly since 2001: at least 4 bat species such as Rhinolophus hipposideros, Myotis dasycneme, Barbastella barbastellus, Plecotus auritus occur here in different seasons. In particular, Adit N 1 serves as wintering shelter for the most abundant colony of Rhinolophus hipposideros in the Park (Fig. 3): 67 individuals in 2011, 58 in 2012, 33 in 2013, 67 in 2014, 73 in 2015, and 112 in 2016. A wintering colony of this species consisting of 10 to 23 individuals was discovered in 2016 in Adit N 2 as well. 


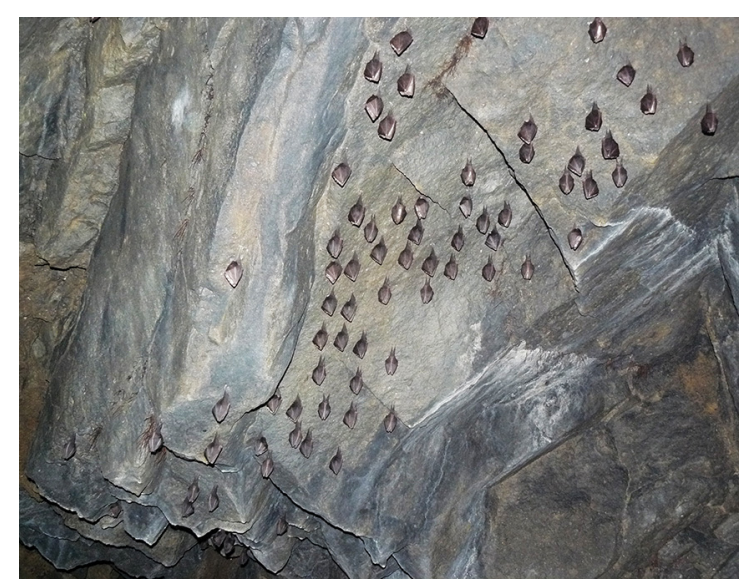

Fig. 3. The colony of Rhinolophus hipposideros in Adit $\mathrm{N} 1$ near Zahorb village.

Рис. 3. Колонія Rhinolophus hipposideros в штольні № 1 у с. Загорб.

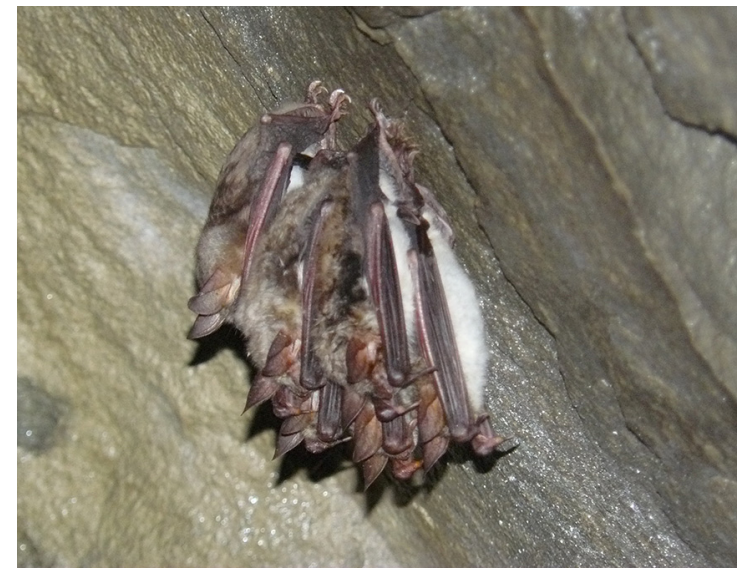

Fig. 4. The colony of Myotis myotis in a cave, Krasiia Mt. near Vyshka village.

Рис. 4. Колонія Myotis myotis в печері на г. Красія в околиці с. Вишка.

Bats can be also found in caves that are located on mountain ridges around 1,000 $\mathrm{m}$ a.s.1. In the Stinka cave, which is located on a ridge of the same name on $1,019.4 \mathrm{~m}$ a.s.l. at the state border with Slovakia, two species of bats were discovered: Rhinolophus ferrumequinum and $R$. hipposideros in the winter and $R$. hipposideros in the summer.

According to the information given by speleologists from Uzhhorod (M. Levinets and O. Monych, person. comm.), three bat species can be found in the cave complex on Krasiia Mt., namely Myotis myotis, Rhinolophus hipposideros, and Myotis emarginatus. In one cave, a colony of Myotis myotis consisting of 6 individuals was discovered (data of N. Koval, 2013) (Fig. 4).

The high species diversity of the bat fauna shows the natural value of the territory of the Uzhanskyi National Park. Large areas of mature deciduous and mixed forests with a significant number of hollow trees create suitable conditions for the existence of tree-dwelling bat species. The neighbouring Transcarpathian plain with its warmer climatic conditions affects the presence of Mediterranean thermophile species in the Park. The relatively dense human occupancy of fluvial terraces of the Uzh river and of its main tributaries, and, as a result, the presence of villages surrounded by large-scale deforested and grassland-shrubby areas contribute to the distribution of generalist bat species.

The presence of a large number of summering and wintering shelters in the Park's territory highlights the significance of these locations as habitats for bats, as well as the importance of conservation and protection of such places.

Based on analysis of research results on general distribution and localization of places of bats' concentration, several sites were selected in the territory of Uzhanskyi National Park that need increased conservational attention and protection, first of all to secure existing caves, in which bats were detected, from uncontrolled disturbances by humans. Protective zones were created in adjacent to the caves territories and in sites of forests with mature hollow trees suitable for settle by bats in order to prevent changes that can be caused by deforestation or recreational use. These zones are to be taken into consideration during implementation of forest management and biotechnical measures.

The discovered by us breeding sites, sites of maternity colonies, summering and wintering shelters of bats are indicated on the Park's map as protected zones with a radius of at least $200 \mathrm{~m}$. Constant monitoring, ban of all kinds of forest management activities and visiting by tourists are provided. The list of the sites was approved by the decree of the director of the Park. Heads of Conservation and Scientific Research Departments are also informed and requested to provide protection and conservation of these zones. 


\section{Acknowledgements}

The research was conducted in frames of the project "Acoustic monitoring of bats in the Ukrainian Carpathians" and financially supported by the Frankfurt Zoological Society, Germany and the Ukrainian Society for the Protection of Birds. Data analysis was carried out by the authors (A.-T. Bashta) and by M. Dietz, M. Weitzel, E. Krannich, and A. Krannich, researchers of the Institute of Animal Ecology and Nature Education, Germany.

The authors would like acknowledge I. Ivaneha, M. Kapral, and V. Pokynchereda for cooperation and sharing their data. During research, we received assistance and support from M. Levinets and O. Monych, from members of "Lynx" adventure group from Uzhhorod, from the workers of Conservation and Scientific Research Departments in Lubnia, Nova Stuzhytsia, Zhornava, Kostryna and Uzhok, from V. O. Kopach, former director of the Uzhanskyi NNP and from V. Byrkovych, present director of the Park. We are also grateful to I. Zagorodniuk for his help in preparing the manuscript and to Z. Barkaszi for its translation into English.

\section{References • Література}

Bashta, A.-T. V., N. P. Koval. 2013 a. The species diversity, distribution and problems of protection of bats (Chiroptera) in Uzhanskyi National Park. Scientific Notes of the State Natural History Museum. Lviv, 29: 19-32. (In Ukrainian) [Башта, А.-Т., Н. П. Коваль. 2013 а. Видова різноманітність, особливості поширення та проблеми охорони кажанів (Chiroptera) Ужанського НПП. Наукові записки Державного природознавчого музею. Львів, 29: 19-32.]

Bashta, A.-T. V., N. P. Koval. 2013 b. Old-growth forests of the Uzhanskyi NNP as important habitats for rare bat species (Chiroptera). In: Primeval and Ancient Beech Forests of Europe: Problems of Protection and Sustainable Use. Proc. Intern. Conf. (Rakhiv, September 16-22, 2013). CE Uzhgorod City Publ. House, Uzhgorod, 21-24. (In Ukrainian) [Башта, А.-Т., Н. П. Коваль. 2013 b. Старовікові букові ліси Ужанського НПП важливі оселища рідкісних видів рукокрилих (Chiroptera). Букові праліси та давні букові ліси Свропи: проблеми збереження та сталого використання: Матер. Міжнар. конф. (м. Рахів, 16-22.09.2013). КП Ужгород. міська друк, Ужгород, 21-20.]

Bashta, A.-T. V., N. P. Koval. 2014. The bats as a part of the rare fauna of the territory of Uzhanskyi N. P. In: Biodiversity of protected objects in Carpathians. Proceedings of the International Conference (vil. Synevyr, 25-27.06.2014). Patent, Uzhgorod, 18-20. (In Ukrainian)

[Башта, А.-Т., Н. П. Коваль. 2014. Рукокрилі як раритетна складова фауни території Ужанського НПП. Біоло- гічне різноманіття природно-заповідних об'єктів Карnam : Матеріали міжнар. наук. конф. (с. Синевир, 2527.06. 2014). Патент, Ужгород, 18-20.]

Krichfalushiy, V. V., I. Yu. Ivaneha, O. E. Lugovoi et al. 2001. Uzhansky National Park. Uzhgorod, 112-113. (In Ukrainian) [Крічфалушій, В. В., І. Ю. Іванега, О. Є. Луговой та ін. 2001. Ужанський національний природний парк. Ужгород, 1-112.]

Krochko, Yu. I. 1994. Pond bat Myotis dasycneme Boie, 1825. In: Red Data Book of Ukraine. Animals. Ukrainian Encyclopedia, Kyiv, 379. (In Ukrainian)

[Крочко, Ю. І. 1994. Нічниця ставкова Myotis dasycneme Boie, 1825. Червона книга Украӥни. Тваринний світ. Українська енциклопедія, Київ, 379.]

Miller, B. W. 2001. A method for determining relative activity of free flying bats using a new activity index for acoustic monitoring. Acta Chiropterologica, 3 (1): 93-105.

Mitchell-Jones, A. J., A. P. McLeish. 1999. The bats workers' manual. JNCC. 1-138.

Zagorodniuk, I., O. Godlevska, V. Tyshchenko, Ya. Petrushenko. 2002. Bats of Ukraine and Adjacent Countries: a Guide for Field Investigations. Kyiv, 1-108. (Proceedings of the Theriological School; Vol. 3). (In Ukrainian)

[Загороднюк, I. В., О. Годлевська, В. Тищенко, Я. Петрушенко. 2002. Кажани Украӥни та суміжних крайн: керівництво для польових досліджень. Київ, 1-108. (Праці Теріологічної школи; Вип. 3)] 